\title{
PROMOCJA STATUSU RODZINY I KOBIETY W PEDAgOgiCZNYCH POGLĄDACH ALEKSANDRA WÓYCICKIEGO
}

The promotion of the status of the family and women in the pedagogical views of Aleksander Wóycicki

\begin{abstract}
S u m m a ry: In the writings of Aleksander Wóycicki we see the promotion of the status of women and the family. The family is considered as a temple, while the woman is treated as a priestess. Understood as a small society, the family is understood to be the basis of the wider society and nation. Wóycicki identifies the collapse of the family with the collapse of the entire society. Yet, he connects its fall to the earlier "fall" of women - by which he means a wide emancipation of women which deprives them of men's protection. In his texts, Wóycicki also outlines plans for the repair of the situation of the family, as well as of the woman and her child. This plan involves the woman's right to self-protection and to the protection of her work, especially during pregnancy and motherhood. Furthermore, this plan can be implemented at the present time.
\end{abstract}

Key w o r d s: Aleksander Wóycicki, family, protection of the family, women, social justice

\section{Wprowadzenie}

Człowiek i społeczeństwo ze wszystkimi swoimi formami życia oraz grupami społecznymi znajdują ważne miejsce oraz istotne do dziś ujęcia w pracach naukowych Aleksandra Wóycickiego ${ }^{1}$ - wybitnego międzywojennego profesora, zajmującego się działalnością

\footnotetext{
${ }^{1}$ Aleksander Wóycicki (1878-1954) - ur. w Mistowie koło Nowomińska pod nazwiskiem Wojcicki, całe życie podpisywał sięjako Wóycicki. W 1896 r. wstąpił do Metropolitalnego Seminarium św. Jana Chrzciciela przy kościele Karmelitów na Krakowskim Przedmieściu, święcenia kapłańskie przyjął w Kościele Archikatedralnym Warszawskim. Wraz z robotnikami z Żyrardowa założył spółdzielnię robotniczą „Żubr”. W 1906 r. wyjechał do Paryża - studiował na wydziale prawa Uniwersytetu Paryskiego i w Szkole Nauk Politycznych. Po dwóch latach otrzymał dyplom i wyjechał na dwa miesiące do Londynu, gdzie uczeszczał do „School of Economics”, tam przygotowywał się do doktoratu. Następnie studiował w Lowanium pod Brukselą. Jako pierwszy spośród polskich księży otrzymał stopień doktora nauk politycznych i społecznych na podstawie pracy „Klasa robotnicza w wielkim przemyśle Królestwa Polskiego". W1915 r. zorganizował szkołę dla dzieci wygnańców, a w 1917 powołał
} 
oświatową, społeczną i kulturalną. Dla Wóycickiego człowiek jest ,jestestwem żyjącym”, jednostką indywidualną, niepodobną do żadnej innej, bytem wolnym, samorządnym i myślącym, jak również podmiotem praw i obowiązków, odpowiedzialnym za swe czyny. Ma on wartość samą z siebie, gdyż jest celem samym w sobie.

Wóycicki podkreśla, że człowiek nie jest przyrządem do pracy czy środkiem usługującym zbiorowości. Jego zadaniem jest osiągnięcie swojego przeznaczenia, w czym mają mu pomóc prawa, jakie posiada (inni muszą je szanować) oraz obowiązki, jakie musi wypełnić. Najważniejsze z praw to prawo do życia i do wolności ${ }^{2}$. Wolność (słowa, osobista, prasy, zebrań, związków i stowarzyszeń) stanowi dla Wóycickiego podstawę do budowania społeczeństwa i warunek zaistnienia demokracji. Sztuką życia jest zaś poznanie samego siebie i drugiego człowieka - pierwsze pozwala na kierowanie sobą, a drugie - na oddanie innym tego, co im się należy33. Wóycicki uznaje religijność natury ludzkiej, dowodem czego ma być odczuwanie przez jednostkę potrzeby Boga, adekwatnej do „potrzeby chleba”. Odwołując się do filozofii Arystotelesa i św. Tomasza uznaje istnienie w człowieku dwóch ,jestestw” (natur): indywidualnego i społecznego. Pierwsze, złożone ze stanów duchowych, wyraża osobowość ludzką. Drugie to system idei, nawyków i uczuć, stanowiących całość. Naturę społeczną człowieka stanowią oba jestestwa4.

W mowie rektorskiej opublikowanej w Wilnie w roku 1938 Wóycicki stwierdzil, że osoba ludzka urzeczywistnia się i wzbogaca swoje życie przez solidarność z rodakami. Człowiek „pełny” żyje w społeczeństwie i dla społeczeństwa, jednak, aby to nastąpiło, musi znać to społeczeństwo i jego potrzeby5. W znacznym stopniu jest też wytworem środowiska, w którym żyje ${ }^{6}$.

Poglądy Aleksandra Wóycickiego wpisują się w nurt pedagogiki rodziny (pedagogii chronienia rodziny), obecnej w Polsce w dwudziestoleciu międzywojennym. Inni jej przedstawiciele to między innymi Konstanty Michalski,

Towarzystwo Pomocy dla Ofiar Wojny. Był profesorem Katolickiego Uniwersytetu Lubelskiego (1919-1937), profesorem i rektorem Uniwersytetu Stefana Batorego w Wilnie (1937-1939), profesorem na wyższych kursach Polskiej Macierzy Szkolnej oraz posłem na Sejm Rzeczypospolitej Polskiej (1922-1927) - piastował stanowisko prezesa Komisji Ochrony Pracy (uczestniczył w wielu konferencjach Ligii Narodówi zjazdach Komisji Technicznych w różnych miastach Europy m.in. w Londynie, Paryżu, Pradze i Brukseli). Jako poseł walczył o zasiłki dla osób bezrobotnych oraz zabezpieczenia socjalne dla ofiar wypadków przy pracy, był jednym z twórców projektu ustawy o wspieraniu budowy domów mieszkalnych i rozwijał działalność spółdzielczą w Warszawie. Po drugiej wojnie światowej prowadził wykłady w Seminarium Metropolitalnym (1948-1954). Zmarł wWarszawie. Źródło: http://www.kul.pl/ks-prof-aleksander-woycicki,art_26895.html [dostęp 27.07.2016].

2 Aleksander Wóycicki, Wychowanie społeczeństwa (Lublin: Drukarnia „Narodowa” 1938), 5.

${ }^{3}$ Tegoż, Religia i naród (Warszawa: Drukarnia K. Kopytowski i S-Ka 1918), 7, 12.

${ }^{4}$ Tegoż, Rola wychowania w naprawie niesprawiedliwości społecznej (Poznań: Czcionkami Drukarni Wydawnictwa Fr. Krajna 1936), 16.

${ }^{5}$ Tegoż, Mowy rektorskie (Wilno: Druk J. Zawadzki, 1938), 13.

${ }^{6}$ Tegoż, Co to jest wspótczesny uniwersytet? Wykład publiczny na rozpoczęcie roku akademickiego poprzedzony mowa rektorską przy objęciu wtadzy w U.S.B. (Wilno: Druk J. Zawadzki 1938), 41. 
Andrzej Niesiołowski, Ludwika Dobrzyńska-Rybicka, Karol Górski, Maria Śliwińska, Stefan Biskupski i Stanisław Podoleński .

Położenie rodziny na początku XX wieku było konsekwencją szeregu czynników politycznych i społecznych. Budowaniu więzi rodzinnych nie sprzyjały złe warunki mieszkaniowe, ubóstwo, całodniowa praca w fabrykach, również kobiet i dzieci oraz brak ochrony prawnej kobiety pracującej, zwłaszcza w okresie połogu. Ponadto migracje w poszukiwaniu zatrudnienia przez anonimowość życia w nowym miejscu wzmagały negatywne zachowania jednostek. Zagrożenie stwarzał napływający z Rosji bolszewickiej komunizm niosący ze sobą zniszczenie ram społecznych, rodzinnych i religijnych oraz wszystkiego, co ma atrybut stałości, co uświadamiały społeczeństwu środowiska katolickie ${ }^{8}$. Na powyższe czynniki zwracał uwagę w swych pismach również Wóycicki - widział w nich przyczynę kształtowania złych nawyków w społeczeństwie, mających negatywny wpływ na rodzinę. Obok nich wymieniał pierwszą wojnę światową, uważając ją za wyzwolicielkę instynktu niszczycielskiego w ludziach 9 .

Celem niniejszego artykułu jest naszkicowanie jakże interesujących i nowoczesnych poglądów społecznych i pedagogicznych Aleksandra Wóycickiego (odnoszących się do rodziny i jej roli społecznej oraz funkcji socjalizacyjno-wychowawczej, podejmowanej w stosunku do wychowujących się w niej dzieci).

\section{Wychowanie w rodzinie}

W pismach Wóycickiego rodzina jest istotnym elementem szerszej koncepcji wychowania, które można określić mianem wychowania do sprawiedliwości społecznej. W dążeniu do niej za niezbędny uznaje Wóycicki wysiłek nad moralnym urobieniem człowieka oraz pracę wewnętrzną nad samym sobą. Ratunku każe szukać w silnym charakterze, który najpierw musi zostać wyrobiony w chrześcijańskiej rodzinie, a dopiero potem wzmocniony przez instytucje oświatowe, religijne, pomocniczo-kulturalne i warunki pracy. Duże znaczenie przypisuje nowemu ogólnonarodowemu wychowaniu. Uważa, że szkoła (obowiązkowa dla wszystkich)

${ }^{7}$ Janina Kostkiewicz, „Pedagogika rodziny w Polsce (1918-1939) - koncepcja i jej konteksty tworzone w kulturze katolickiej”, w: Janina Kostkiewicz, Milan Krankus, Ivan Podmanicki, Wychowanie - rodzina spoteczny rozwój osoby. Studia ze spotkań krakowsko-bratysławskich (Kraków: Wydawnictwo Uniwersytetu Jagiellońskiego 2015), 89-91.

${ }^{8}$ Środowiska katolickie, zdając sobie sprawę z zagrożenie jakie dla człowieka i rodziny niósł wdrażany w Rosji bolszewickiej komunizm, uświadamiały społeczeństwu to zagrożenie. Pisali o tym m.in. Pius XI, „Divini Redemptoris - o bezbożnym komunizmie", w: Socjalizm i komunizm potępiony przez papieży, red. Aneta Maniecka (Sandomierz: Wydawnictwo Diecezjalne 1937), 142-172; Stanisław Podoleński, Rodzina w sowietach (Kraków: Wydawnictwo Księża Jezuici 1938); Antoni Szymański umieścił rozdział „Zniszczenie rodziny” w: „Bolszewizm jako prąd kulturalny i cywilizacyjny”. Prąd 32 (1937), 232. Za: Janina Kostkiewicz, „Krytyka warstwy wychowawczej totalitaryzmu komunistycznego lat dwudziestych i trzydziestych XX wieku w pismach Antoniego Szymańskiego", w: W shuzbie nauki, wychowania i wartości. Szkice biograficzne olubelskim środowisku naukowym, red. Ryszard Skrzyniarz i in. (Lublin: Wydawnictwo EPISTEME 2015), 439-455.

${ }^{9}$ Aleksander Wóycicki, Potęga przykładu (Warszawa: Księgarnia Polska Polskiej Macierzy Szkolnej 1921), 14. 
i nowe wychowanie (z pomocą rodziny i Kościoła) są w stanie uzdrowić całe społeczeństwo ${ }^{10}$ - to samo dziać się winno także w rodzinie. Postulując obowiązkową edukację, opowiada się za wprowadzonym najpierw w roku 1919, później w 1932 obowiązkiem szkolnym ${ }^{11}$. Dla Wóycickiego „nie ma skuteczniejszego lekarstwa, jak tylko w otwartym i szczerym powrocie do nauki Ewangelii w ogóle, w szczególności zaś w chrześcijańskim wychowaniu, które ostatecznie do tego zmierza, by zapewnić duszom wychowanków najwyższe dobro - Boga, ludzkiej społeczności najwyższy stopień możliwego na tej ziemi dobrobytu"12.

W swych pismach Wóycicki sprzeciwia się wychowaniu świeckiemu, jako że prowadzi do zniewolenia człowieka, które ma się odbywać właśnie przez „całkowite zaświecczenie wychowania"13. Za jego fundament uznaje fałszywe przekonanie, że człowiek stanowi najwyższą wartość, jest samowystarczalny i zależny wyłącznie od siebie. W wychowaniu tym dostrzega dążenie do wyzwolenia człowieka z wszelkich dogmatów oraz urabianie jednostek poprzez wyposażenie ich w wiadomości zdobyte jedynie drogą doświadczenia ${ }^{14}$.

W definicji wychowania, jaką formułuje Wóycicki, jest ono przygotowaniem młodego pokolenia do życia w społeczeństwie. Stanowi jeden z czynników uspołeczniających: umożliwia życie ludzi w zbiorowości i porządek społeczny. Wśród tych czynników znalazły się także mowa oraz cywilizacja rozumiana jako rozwijanie $\mathrm{w}$ jednostce religii, wiedzy oraz kultywowanie tradycji i współdziałanie z bliźnimi ${ }^{15}$. „Przez religię i naukę wytwarza on [człowiek - przyp. J.L.] w sobie kardynalne pojęcia, na jakich wspiera się całe jego życie duchowe, przez moralność kształtuje w sobie wolę, wyższą od pragnień i niskich instynktów, przez mowę wznosi się ponad proste zmysłowo-zwierzęce doświadczenia"16 - pisze Wóycicki w Wychowaniu społeczeństwa.

Wartość rodziny wynika z wprowadzania jednostki do społeczeństwa, co odbywa się przez wychowanie i kształcenie (przy czym Wóycicki nie rozgranicza ich, uznając kształcenie za wychowywanie). Najlepszą szkołą wychowania jest dla Wóycickiego rodzina, to ona najlepiej przygotowuje do życia społecznego i zawodowego, nawet pedagogika nie wynalazła nic lepszego. Uważa, że żadna szkoła czy zakład wychowawczy nie są w stanie wzbudzić w dziecku tak szerokiej gamy uczuć jak rodzina, która kształtuje charakter i duszę dziecka, uczy

\footnotetext{
${ }^{10}$ Wóycicki, Religia, 133.

${ }^{11}$ W Polsce 7 lutego 1919 r. został wydany dekret o obowiązku szkolnym, który wprowadzał obowiązkowe wykształcenie z zakresu szkoły powszechnej (7-letniej) dla wszystkich dzieci od 7 do 14 roku życia. Zwalniano z niego m.in. dzieci, których droga do szkoły przekraczała trzy kilometry (problem ten miały osoby głównie ze środowisk wiejskich). Źródło: Dz. Urz. Min. WRiOP, 1919, nr 2. Ustawa z 11 marca 1932 roku wprowadziła 7letni obowiązek szkolny dla dzieci z miasta i ze wsi. Źródło: Dz.U. 1932 nr 38 poz. 389.

${ }^{12}$ Wóycicki, Wychowanie, 31-33.

${ }^{13}$ Tegoż, Co to jest współczesny, 38.

${ }^{14}$ Tegoż, Wychowanie, 24-27.

${ }^{15}$ Tegoż, Rola, 9, 16.

${ }^{16}$ Tegoż, Wychowanie, 28.
} 
je tradycji oraz życia umysłowego i moralnego ${ }^{17}$. Dla Wóycickiego nie ma wychowania bez udziału rodziny, nie ma też jego ujednolicania dla wszystkich - „zmienia się ono stosownie do swego własnego pojmowania natury ludzkiej, tudzież jej przeznaczenia" 18 .

W pismach Wóycickiego rodzina stanowi podstawę wychowania moralnego jest fundamentem czynników moralnych, takich jak sumienność, wzajemny szacunek, odpowiedzialność i uczciwość, a zanik małżeństwa i życia rodzinnego prowadzi do zaniku moralności (z uwagi na rozwój przemysłu i postęp społeczny autor widział konieczność nowoczesnego wychowania, szczególnie moralnego ${ }^{19}$ ). W ujęciu Wóycickiego wychowanie moralne nie polega na wykładach temu poświęconych, ale jest wynikiem przekonań decydujących o wyborze drogi życiowej i nawyków wpływających na kierunek oraz skuteczność działań. Wymienia przy tym wiele czynników utrwalających nawyki i przekonania, takich jak nauka, zdobyte wiadomości, zasady religijne oraz moralne, doświadczenia osobiste, a także słyszane od dzieciństwa zdania. Za ich podstawę uznaje jednak sposób życia rodziców będący przykładem dla dziecka, który jest najważniejszy, na co wielokrotnie zwraca uwagę, podkreślając jednocześnie, że zły przykład niszczy życie moralne ${ }^{20}$. Przy czym drogę do bycia sprawiedliwym widzi tylko w przestrzeganiu praw moralnych, które uznaje za ponadczasowe jako obowiązujące sumienia ludzkie ${ }^{21}$ - prawa ludzkie, jako, że regulują wyłącznie czyny publiczne zostały uznane za nietrwałe.

Szczególną uwagę w dawaniu dobrego przykładu zwraca Wóycicki na zabiegi pielęgnacyjne, jakie wykonują matki względem swego potomstwa; wskazuje przy tym na ówczesną niewiedzę kobiet w tej kwestii. Jako że zabiegi te będą powielane, za konieczne uznaje przygotowanie kobiet do opieki nad niemowlakami i dziećmi ${ }^{22}$. Ważnym w wychowaniu jest rozumienie i branie pod uwagę rozwoju fizycznego oraz psychiki dzieci, czego brak ukazuje wśród rodziców-robotników. Dbanie o rozwój fizyczny i kondycję potomków (tu autor zaleca gimnastykę i zabawy rozwojowe) stawia na równi z kształtowaniem ich umysłu i charakteru. Poza dbaniem o dziecko, równie ważne jest dla Wóycickiego poczucie dziecka, że jest objęte troską, przy czym negatywnie oceniane jest przesadne zajmowanie się nim, jako że w efekcie powoduje to powstawanie poczucia bezsilności i bierności. Dzieci chce uczyć polegania na samych sobie, ale jednocześnie muszą one mieć świadomość, że mogą komuś bezgranicznie ufać, mają na kogo liczyć i do kogo się zwrócić w razie potrzeby. Uważa, że powinny czuć się otoczone osobami silniejszymi, zarówno pod względem

17 Aleksander Wóycicki, Robotnik polski wżyciu rodzinnym. Monografia społeczna (Warszawa: Drukarnia I Litografia p. f. „Jan Cotty” 1922), odbitka z Ekonomisty 1918-1922, 17, 34-35.

${ }^{18}$ Wóycicki, Wychowanie, 4.

${ }^{19}$ Tegoż, Robotnik, 113-114.

20 Tamże, 64, 127-128.

${ }^{21}$ Wóycicki, Religia, 10.

22 Tamże, 88-89, 109. 
fizycznym, moralnym jak i umysłowym, ale siła ta ma stanowić dla nich podporę oraz wsparcie, tylko w taki sposób będą mogły stać się dobre, mądre i miłe²3.

\section{Rodzina jako fundament społeczeństwa i narodu}

Czymże zatem jest dla Wóycickiego rodzina? Nazywa ją „świątynią”, zaś kobietę jej „kapłanką̧"24 i w taki sposób o nich pisze. Rodzinę definiuje socjologicznie, co jest konsekwencją przyjęcia takiej perspektywy w interpretowaniu rzeczywistości. Uznaje ją za wytwór społeczny istniejący prawie od początku trwania ludzkości oraz czynną komórkę organiczną tworzą cą naród - to od niej zależy przyszłe życie narodu i społeczeństwa, którego rodzina jest podstawą oraz wzorem, ponieważ stanowi jego miniaturę, a jej spójność albo rozkład decyduje o jego stanie. Na niej właśnie opierają się siły narodu, zarówno twórcze, jak i rozkładowe. Głównym celem, jaki Wóycicki stawia rodzinie, jest wydanie i zachowanie życia; kolejnym - przekazywanie z pokolenia na pokolenie tradycji zawodowej i kultu pracy. Odnosząc się do obecnej w dwudziestoleciu międzywojennym komunistycznej wizji rodziny jako instytucji zbędnej, Wóycicki podkreśla, że negowanie lub odrzucenie jej istnienia nie jest możliwe bez negatywnych konsekwencji dla ladu społecznego, ponieważ rodzina nie powstała w ramach umowy między jednostkami, jak uważały niektóre środowiska w tamtym czasie, ale jest wytworem społecznym. „Błądzeniem” nazywa myślenie socjalistów, jakoby rodzina była formą przejściową. Wóycicki jest przekonany, że rodzina będzie trwała zawsze, może się jedynie zmienić jej kształt. „Żadna inna instytucja ludzka nie jest $\mathrm{w}$ stanie zastąpić rodziny, $\mathrm{zchwilą}$ u padku rodziny upada całe społeczeństwo ”25-pisze.

Wyrażając opinię, że rodzina i ognisko domowe, jakie tworzy, jest i zawsze będzie "niezastąpioną i najcenniejszą instytucją wychowawczą "26, pisze jednocześnie o niekochanym dziecku, które pozbawione ogniska domowego nie ma szans na normalny rozwój, choćby niczego materialnego mu nie brakowało. Ogniskiem domowym określa Wóycicki szczególnego rodzaju środowisko wytwarzane przez wspólnotę rodzinną - bez niego ona nie istnieje. Wymienia tu czynniki konieczne do powstania ogniska domowego oraz niszczące je. Wśród pierwszych za istotne uznaje warunki mieszkaniowe - dom ma być miejscem wypoczynku i zadowolenia obfitującego w cnoty; ma budzić pragnienie przebywania wnim; posiadać odpowiednie, dobrze wyposażone pomieszczenia (na przykład kuchnię, sypialnie) oraz przestrzeń do pracy i odpoczynku dla wszystkich jej członków; ma być odpowiednio zabezpieczony przed żywiołami oraz osobami z zewnątrz; ma w nim panować ciepło, suchość i czystość.

\footnotetext{
${ }^{23}$ Wóycicki, Robotnik, 128-129.

${ }^{24}$ Tamże, 110-112.

${ }^{25}$ Tamże, 17, 34-35.

${ }^{26}$ Tamże, 128.
} 
Konieczne jest też, aby rodzina mieszkała w domu przez dłuższy czas ${ }^{27}$ - Wóycicki nie precyzuje jednak, jak długi ma to być okres.

Wśród czynników mających destrukcyjny wpływ na ognisko domowe Wóycicki wymienia: ubóstwo, niezadowolenie, nudę oraz borykanie się rodziny z pożyczkami i długami. Warunki mieszkaniowe ówczesnych robotników nazywa „wstrętnymi norami” i uznaje je za powód wszystkich nieszczęść oraz problemów tej warstwy społecznej. W takim miejscu spracowany robotnik nie spotyka uśmiechu, troski i czułości potrzebnych do wytchnienia - jego ognisko domowe jest smutne i zimne, a tym samym nietrwałe. „W chwili gdy praca przemysłowa czyni życie rodzinne niemożliwym lub trudnym zaczyna się bezwład i zanika szczęście. Koniecznym jest by praca, poza godzinami wolnymi, dawała pracownikowi dobrobyt"28 - pisze.

Fundamentem rodziny jest dla Wóycickiego małżeństwo: „tyle wart jest naród ile warte społeczeństwo; tyle warte społeczeństwo jak i poszczególny stan społeczny ile warta rodzina; tyle warta jest rodzina, ile warte małżeństwo"29. Małżeństwo nie stanowi dla niego jedynie umowy między jednostkami - co funkcjonowało w ówczesnym prawie, wraz z przyzwoleniem na rozwód, już od początku lat dziewięćdziesiątych XVIII wieku - małżeństwo jest warunkiem szczęścia3o.

Przypisując tak dużą wagę małżeństwu, za jedną z najważniejszych spraw w życiu człowieka uznaje Wóycicki przygotowanie do małżeństwa - podobnie jak inni współcześni mu pedagodzy rodziny, na przykład Stanisław Podoleński3i. Miałoby się ono rozpoczynać już w dzieciństwie, głównie przez tradycję i dobry przykład płynący z ogniska domowego - w ich braku Wóycicki upatruje przyczyny związków „na wiarę” i rodzenia nieślubnych dzieci. Jego zdaniem wychowanie poza rodziną pozbawia człowieka „czaru”, jaki ona daje oraz świadomości własnych oczekiwań względem osoby, z jaką zamierza się zawrzeć małżeństwo ${ }^{32}$.

W istnieniu rodziny Wóycicki widzi wartość dla wszystkich jej członków. Rozwijają się w niej ludzkie charaktery, obyczaje i tradycje oraz cnoty indywidualne, a także społeczne, stanowiące duszę narodu. W rodzicach rozwija ona najlepsze zalety i stwarza poczucie, iż stanowią ogniwa łańcucha (będą „żyć” w swych potomkach), dzięki czemu żadna praca czy troska nie wydaje im się ponad siły. Zwiększa też chęć ojców do pracy, ponieważ jej wytwory chcą oni pozostawić potomstwu. Z kolei dzieci uczą się w niej pracy, miłości i szacunku, co okazują w późniejszym życiu publicznym. Rodzina poprzez nałożenie na swych członków konkretnych obowiązków zwalcza

${ }^{27}$ Tamże, 128-129.

${ }^{28}$ Tamże, 70.

${ }^{29}$ Tamże, 61.

${ }^{30}$ Tamże, 34-35.

${ }^{31}$ Stanisław Podoleński, U progu. Ksiażka dla młodych (Kraków: Wydawnictwo Apostolstwa Modlitwy), 77. Za: Janina Kostkiewicz, Wychowanie-rodzina-społeczny rozwój osoby (Kraków: Wydawnictwo Uniwersytetu Jagiellońskiego 2015), 87-94.

${ }^{32}$ Wóycicki, Robotnik, 63-66. 
egoistyczny instynkt człowieka. $\mathrm{W}$ obliczu powyższego, dzięki poświeceniu swojego życia dla drugiego człowieka, rodzina jest dla Wóycickiego $\mathrm{n}$ a j l e p s z ą s z k o ł ą s p o ł e c z n ą, ,wielką szkołą postępu osobistego, poświęcenia i ofiary, wyrzeczenia się i pracy" 33 . Jego zdaniem ludzkość przetrwała wyłącznie dzięki dziedziczeniu poświęcenia obecnego w rodzinie, które (wraz z miłością łączącą jej członków) uznaje za cechy właściwego społeczeństwa 34 .

Rozwinięciem uczuć rodzinnych jest w ujęciu Wóycickiego miłość do swojego narodu. Rodzina przywiązuje człowieka do ojczyzny i jest fundamentem powstawania miłości do innych członków społeczeństwa. $Z$ miłości, jak pisze dalej, wychowanie i czas wytwarzają patriotyzm, obyczaje, obowiązki oraz ten sam język. Dla Wóycickiego „rodzina jest konieczna do istnienia i moralnej jedności ojczyzny. Kto przestaje ją kochać, jest w niebezpieczeństwie utracenia miłości ojczyzny, czyli największej siły społecznej” 35 . W rodzinie widzi też siłę wy chowawc zą $\mathrm{n}$ a r o d u . To ona jest w stanie usunąć wszystkie nierówności i zagrożenia wobec niego płynące. Bez rodziny - wytwórczyni wartości moralnych człowieka ${ }^{36}$ - zdrowe życie społeczne wydaje się Wóycickiemu wręcz niemożliwe.

\section{Konieczność ochrony kobiety i rodziny}

Pisma Aleksandra Wóycickiego są cennym źródłem informacji o sytuacji rodziny na początku XX wieku - zamieszczone tam opisy są dobitne i klarowne. Autor często odnosi się $w$ nich do sytuacji kobiet ciężarnych i młodych matek, wyrażając zaniepokojenie, że ochrona pracy kobiet jest całkowicie zaniedbana, a sama kobieta - bezkarnie wyzyskiwana. Krytykuje brak odpowiednich przepisów prawnych chroniących kobietę przed, w trakcie i po ciąży oraz zwraca uwagę na potrzebę ich powstania. Stanowisko takie znajdujemy zwłaszcza w „Robotniku polskim w życiu rodzinnym” (1922), „Podstawach moralnych 8 godzinnego dnia pracy” (1925) i piśmie „Religia i naród” (1918). Warto zaznaczyć, że pierwsze projekty prawodawstwa wobec matek i ich nowonarodzonych dzieci powstawały na ziemiach polskich od 1907 roku37, zaś ustawa zakładająca (w niewielkim stopniu) ochronę macierzyństwa pochodzi z 2 lipca $1924 \mathrm{roku}^{38}$.

\footnotetext{
${ }^{33}$ Tamże, 35 .

${ }^{34}$ Tamże, 34-35. Zob. też Wóycicki, Wychowanie, 25-26, 39-40.

${ }^{35}$ Wóycicki, Robotnik, 37.

${ }^{36}$ Tamże, 200.

${ }^{37}$ Projekty pojawiły się podczas Zjazdu Kobiet Polskich w Warszawie oraz X Zjazdu Lekarzy i Przyrodników Polskich we Lwowie, zaś pierwsze regulacje prawne wchodzily od 1913 r. Na pierwszym Zjeździe Kobiet Polskich, po wygłoszeniu referatu dr Jaworskiego pt. „Ochrona i ubezpieczenie macierzyństwa” (12 VI 1907 r.) postulowano: zwolnienie kobiet od pracy z zachowaniem wynagrodzenia w okresie od 4 tygodni przed porodem do 4-6 tygodni po nim; otwieranie zakładów mających zapewnić kobiecie ijej dzieciom ochronę w okresie macierzyństwa; ubezpieczenia kobiet w okresie macierzyństwa. Te same postulaty uchwalono na XZjeździe Lekarzy i Przyrodników Polskich. Źródło: Sylwia Silska, Ewolucja poglądów na żywienie niemowląt wXIX iXX wieku [Poznań: niepublikowana praca doktorska 2013], 106.

${ }^{38}$ Chodzi o ustawą z dnia 2 lipca 1924 r. w przedmiocie pracy młodocianych i kobiet (Art. 16.), która wprowadzała przerwę w pracy dla kobiet ciężarnych nie dłuższą niż 6 dni w miesiącu, 6 tygodniowe przerwy
} 
Ochrona rodziny jest najważniejszym zadaniem, jakie Wóycicki stawia społeczeństwu. Na państwo nakłada obowiązek sprawowania nad nią opieki przez mądre prawodawstwo społeczne, zwłaszcza w kwestii kobiet i dzieci. System ochrony praw kobiet, szczególnie w okresie macierzyństwa oraz dzieci uznaje za niezbędny do zapewnienia ojczyźnie zdrowych i zdolnych do pracy obywateli. Przy tworzeniu prawa, które ma odpowiadać duchowi czasu, zaleca współpracę inicjatywy społecznej, prywatnej i państwowej39.

Dla Wóycickiego stan fizyczny i moralny kobiety ciężarnej wymaga szczególnej ostrożności ${ }^{40}$. Za obowiązek państwa uznaje udzielanie pomocy moralnej i materialnej biedniejszym matkom wokresie połogu, a także wynagrodzenie czasu bezrobocia kobiety w ciąży i połogu. Sam zakaz pracy na ten czas bez żadnej pomocy materialnej nie jest dla Wóycickiego wystarczający, ponieważ powoduje, że kobiety, aby nie zostać bez funduszy, ukrywają swój stan, zarówno przed jak i po porodzie. Sytuację, w której matka z powodu ubóstwa zmuszona jest podjąć pracę, oddając swoje dziecko do żłobka, nazywa walką między miłością macierzyńską a nieuniknioną koniecznością. W jego opinii kobiety powinny stać się „płatnymi niańkami własnych dzieci”41.

W Robotniku polskim $w$ życiu zbiorowym42 Wóycicki zwraca uwagę na zatrucia, na jakie jest narażona kobieta podczas pracy w fabryce oraz na inne warunki pracy, które szkodzą jej i dziecku (pisze między innymi o zatruciach tytoniem i ołowiem powodujących problemy z zajściem w ciążę oraz skutkujących porodami martwych dzieci). Warto zaznaczyć, że Wóycicki nie sprzeciwia się pracy kobiet, lecz jedynie zatrudnianiu ich do prac ciężkich (na przykład pod ziemią i w porze nocnej), tym samym opowiada się za wprowadzonymi na mocy ustawy z 2 lipca 1924 roku ograniczeniami pracy kobiet w warunkach niebezpiecznych lub szkodliwych43. Popiera też zrównanie wynagrodzenia kobiet i mężczyzn za taką samą pracę, co było później jednym z głównych haseł drugiej fali feminizmu. Za obowiązek pracodawców Wóycicki uznaje zapewnienie kobietom odpowiednich warunków w pracy, takich jak: oddzielne ubieralnie, miejsce kąpielowe oraz przyfabryczne żłobki zakładane przy zatrudnieniu powyżej stu kobiet, co również wprowadzała ustawa z 2 lipca 1924 roku. W kwestii żłobków Wóycicki wzoruje się na krajach europejskich, w których były one tworzone i chce przeniesienia tego trendu na grunt polski. W ich zakładaniu upatruje możliwość zapewnienia dziecku karmienia piersią w regularnych odstępach czasu, równocześnie wyrażając tym samym swoje stanowisko w toczących się wówczas dyskusjach nad kwestią karmienia dzieci.

przed porodem za okazaniem zaświadczenia lekarskiego oraz zakaz zatrudniania kobiet wcześniej niż 6 tygodni po porodzie. Źródło: Dz. U. 1924 nr 65 poz. 636.

${ }^{39}$ Wóycicki, Robotnik, 200-201.

${ }^{40}$ Tegoż, Religia, 88-89, 109.

${ }^{41}$ Tegoż, Robotnik, 72, 8o-81.

${ }^{42}$ Tamże, 91, 202.

${ }^{43}$ Ustawa wprowadzała zakaz zatrudniania kobiet do prac pod ziemią, w szkodliwych lub niebezpiecznych dla zdrowia warunkach oraz przy pracach ciężkich lub szkodliwych dla moralności i dobrych obyczajów (np. w pracach przy procesach chemicznych, dźwiganiu ciężarów). Źródło: Dz. U. 1924 nr 65 poz. 636. 
Wóycicki postuluje wprowadzenie odpoczynku od pracy dla kobiety bez utraty wynagrodzenia na okres co najmniej trzech miesięcy przed porodem i kilku tygodni po nim (wcześniej pisał o przerwie wynoszącej minimum 2 tygodnie przed i 6 tygodni po porodzie), przy czym zaznacza, że matka powinna mieć możliwość opiekowania się dzieckiem przez pierwsze miesiące jego życia. Postuluje wprowadzenie zakazu eksmisji i zwalniania kobiety w okresie ciąży i po porodzie (nie podaje jak długo miałby on obowiązywać). Natomiast w przypadku złego stanu zdrowia kobiety pracującej Wóycicki sugeruje płatne zwolnienia od pracy za okazaniem zaświadczenia lekarskiego. Troszcząc się o rodzinę i kobietę, pragnie wprowadzenia dla kobiet pracujących czterotygodniowych płatnych urlopów oraz zapewnienia dziennej opieki dla ich dzieci, w jej ramach za istotne uznaje zakładanie ognisk dziecięcych, kolonii i półkolonii oraz wspieranie w tej kwestii inicjatywy prywatnej44.

Negatywnie odnosi się Wóycicki do prawa, które nie przychodzi kobiecie z pomocą $\mathrm{w}$ przypadku nieodpowiedniego dysponowania wspólnym majątkiem przez ich mężów, doprowadzając do zadłużenia rodziny, a w konsekwencji - do zablokowania wypłaty kobiety na poczet wierzytelności. Zwraca uwagę, że separacja naraża kobietę na jeszcze większą nędzę, w związku z czym decyduje się ona pozostać u boku męża, „cierpiąc jak niewolnica i czekając poprawy męża-tyrana” 45 . W okresie międzywojnia z różnych powodów nie weszły w życie powstałe projekty majątkowego prawa małżeńskiego.

$\mathrm{W}$ celu jak najlepszego zabezpieczenia rodziny istotną kwestią są dla Wóycickiego ubezpieczenia rodzin robotniczych. Uznając je za konieczne, opowiada się tym samym za obowiązkowymi ubezpieczeniami wprowadzanymi w niepodległej Polsce najpierw w roku 1919, później - $1933^{46}$. Ich wypłata, według Wóycickiego, powinna następować w przypadku niezdolności do pracy lub jej utraty, macierzyństwa oraz śmierci (gdy zabezpieczeni muszą zostać wdowa i sieroty)47. Jako poseł walczy Wóycicki o zasiłki dla osób bezrobotnych oraz zabezpieczenia socjalne dla ofiar wypadków w pracy.

W swych pismach i nakreślonej tam koncepcji wychowania do sprawiedliwości społecznej, Wóycicki uznaje dzieci za równoprawnych obywateli, podejmując problem ochrony przysługujących im praw. Zwraca uwagę na ich cierpienie oraz śmierć, oskarżając ludzi o zobojętnienie i niską kulturę. W jego opinii

${ }^{44}$ Wóycicki, Robotnik, 200-202.

${ }^{45}$ Tamże, 85 .

46 W 1919 r. wprowadzono w Polsce dekret o obowiązkowym ubezpieczeniu na wypadek choroby i powołano Kasy Chorych. Rok później zastąpiono go ustawą o obowiązkowych ubezpieczeniach na wypadek choroby. Poza pomocą lekarską w okresie do 26 tygodni ubezpieczonym przysługiwał zasiłek pieniężny za każdy dzień niezdolności do pracy z powodu choroby lub połogu - dla osób samotnych wynosił 40\% płacy ustawowej, a dla utrzymujących rodzinę 60\%. W 1933 r. na mocy ustawy (tzw. ustawy scalającej) wprowadzono ubezpieczenia społeczne i zniesiono Kasy Chorych, a wich miejsce powstał Zakład Ubezpieczeń Zdrowotnych. Źródło: Krzysztof Prokop, „Prawo do ochrony zdrowia w świetle art. 68 Konstytucji RP”, w: Uwarunkowania systemu opieki zdrowotnej w Polsce: aspekty prawne i socjologiczne, red. Teresa Mróz (Białystok: Wydawnictwo Temida 2012), 34-35.

${ }^{47}$ Wóycicki, Robotnik, 108, 197. 
poziom cywilizacyjny danego narodu mierzony jest przez stosunek do dzieci: „im bardziej naród jest cywilizowany, tym więcej zajmuje się sprawą dzieci; im zaś mniej jest cywilizowany, tym $\mathrm{w}$ większym zaniedbaniu znajduje się spawa jego najmłodszego pokolenia"48. Wóycicki wyraża przekonanie o możliwości zaistnienia stanu, w którym wszystkie dzieci będą szczęśliwe - uznaje to za cechę humanitarnej kultury. Warunkiem jej powstania jest „zastąpienie” sierotom rodziców przez społeczeństwo poprzez rozpowszechnienie wśród dorosłych jego członków uczuć rodzicielskich, takich jak poczucie odpowiedzialności i troskliwość. Uważa, że dzieci w każdym miejscu na ziemi odczuwałyby ciepło domowego ogniska, jeżeli miałyby poczucie, że wszystkim dorosłym można ufać i czułyby ich życzliwą opiekę49.

Aby zapewnić wszystkim dzieciom odpowiednie warunki do rozwoju, za koniecznie uznaje Wóycicki dostarczenie tym z rodzin najuboższych obuwia, odzieży oraz przyborów i podręczników szkolnych. Pragnąc ochrony życia i zdrowia dzieci, sprzeciwia się ich zatrudnianiu do prac ciężkich i szkodliwych, podobnie jest z pracą dzieci poniżej 14 roku życia. W przypadku młodzieży niepełnoletniej (14-18 lat) pracę dopuszcza tylko za zgodą lekarza, przy czym uznaje, że nie powinna być wykonywana w godzinach nocnych (między 20.00 a 6.00)50. Formułując powyższe postulaty, opowiada się za regulacjami pracy nieletnich jakie wprowadzała ustawa z 2 lipca 1924 roku $^{51}$ - zakazem zatrudniania nieletnich do 15 roku życia, dopuszczeniem młodocianych (15-18 lat) do pracy za zgodą lekarza oraz przerwą od pracy w nocy (nie dla chłopców powyżej 16 lat).

\section{Zagrożenia dla rodziny i kobiety}

W swych pismach Aleksander Wóycicki dokładnie charakteryzuje istniejące zagrożenia wobec rodziny i kobiety. Charakterystyka ta sprowadza się do podsumowania, że wszystkie odsuwają matkę od dziecka. Krytykę rodziny obecną w dwudziestoleciu międzywojennym nazywa „napaścią” i ukazuje ślady jej obecności wśród poetów, publicystów i „wywodowców” 52 .

Jednym z zagrożeń dla rodziny oraz kobiety, wymienionym przez Wóycickiego, jest socjalizm. Uniemożliwia on wytwarzanie w rodzinie wartości duchowych, co ją niszczy, burząc ognisko domowe. Podkreśla, że fundamentem socjalistycznej koncepcji wychowania jest fałszywe rozumienie natury ludzkiej oraz potrzeb dzieci i młodzieży. Za przeciwników rodziny uznaje Wóycicki wszystkich, którzy pod pretekstem dobra kobiety dążą do jej wyzwolenia z „niewoli”, jaką w ich mniemaniu jest małżeństwo. Wyzwolenie to ma się odbyć przez wolny związek

\footnotetext{
${ }^{48}$ Tamże, 73, 109.

${ }^{49}$ Tamże, 129.

${ }^{50}$ Tamże, 201-202.

${ }^{51}$ Dz. U. $1924 \mathrm{nr} 65$ poz. 636, Art. 5-11.

${ }^{52}$ Wóycicki, Robotnik, 51-52.
} 
postrzegany przez niego jako „urządzenie małżeńskie” w kolektywistycznym społeczeństwie. Odwołując się do definicji socjologicznych, stwierdza, że „położenie kobiety jest tym lepsze, im forma małżeństwa zbliża się więcej ku monogamii i nierozerwalności” 3 . Dla Wóycickiego „upadek wielu ludów szedł równolegle z upadkiem życia rodzinnego, obyczajów i z upadkiem kobiety”54. Pisząc o „upadku” kobiety - ma tu na myśli szeroką emancypację kobiet, która pozbawia ją ochrony ze strony mężczyzny.

Niebezpieczeństwo dla rodziny i małżeństwa stanowi dla Wóycickiego samo uzasadnianie związku wolnego „magicznym” słowem „wolność” definiowanym nie jako postępowanie według tego, co powinienem czynić, ale według tego, co „widzi mi się". Popularność takich związków przypisuje propagandzie słownej i pisemnej głoszącej ich wyższość głównie w przypadku niekorzystnej sytuacji materialnej mężczyzn ( $w$ razie utraty pracy $w$ nędzę popada jedynie mężczyzna, a nie cała rodzina) oraz ich propagowaniu przez pracodawców. Za szczególnie podatnych na taką manipulację Wóycicki uznaje ludzi zapracowanych, bezkrytycznych oraz indywidualistów i osoby „ciemne” oraz nieumiejące „oddzielić plew od zdrowej myśli” 55 .

Kolejnym zagrożeniem dla rodziny, jakie wymienia Wóycicki, jest neomaltuzjanizm. Zaniepokojenie wyraża wobec trzech jego głównych postulatów: przekonania, że szczęście społeczeństwu przyniesie pełna swoboda instynktu seksualnego i miłości; nienarzucanie kobiecie ciężaru, jakim jest macierzyństwo; konieczność bezwarunkowego uregulowania i zmniejszenia liczby urodzeń dla większego dobrobytu moralnego i materialnego ${ }^{56}$.

Niebezpieczeństwo dla rodziny stwarza również kapitalizm zakwalifikowany przez Wóycickiego do grona czynników prowadzących do jej zniszczenia. Jego szkodliwe następstwa dokładnie opisuje w Robotniku polskim $w$ życiu zbiorowym. Zwraca tu uwagę, że osoby zmuszone wyjechać w poszukiwaniu zatrudnienia do miast niechętnie zakładają rodzinę. Powodem tego jest, jego zdaniem, chęć uniknięcia przywiązania, jakie by odczuwali po jej opuszczeniu. Nawet gdy młodzi zdecydują się założyć rodzinę, to pracując, pozostawiają dziecko pod opieką niańki/opiekunki, które nie zajmują się nim właściwie, zaś po powrocie do domu, zmęczeni całodniową pracą, nie są w stanie wypełnić należycie swoich obowiązków. „Rodzina nie istnieje tam gdzie matka i ojciec pracują po 14 godzin” 57 - pisze Wóycicki. Zbyt długi dzień pracy powoduje poniżenie moralne człowieka i jego fizyczne wyczerpanie. Dla autora dobrobyt społeczny nie zależy jedynie od czynników materialnych, ale wnajwiększym stopniu od sił duchowych ukazujących cel i nadających kierunek ludzkich działań. W związku z tym postuluje sześciogodzinny

\footnotetext{
${ }^{53}$ Tamże, 46-49.

${ }^{54}$ Tamże, 111.

${ }^{55}$ Tamże, 49-50.

${ }^{56}$ Tamże, 55-58.

${ }^{57}$ Tamże, 42-45.
} 
czas pracy dla kobiet i młodzieży oraz ośmiogodzinny dla mężczyzn; widzi w tym jedyny sposób, aby robotnik mógł wznieść się na wyższy poziom kultury ${ }^{8}$. Zatem nie opowiada się za dekretem z 23 listopada 1918 o 8-godzinnym dniu pracy (48 godzin w tygodniu) i zastępującą go ustawą59 (skracała tydzień pracy do 46 godzin).

Wszelkie zagrożenia dla rodziny wujęciu Wóycickiego są możliwe do usunięcia przez katolicką naukę społeczną, która stanowi oparcie dla życia rodzinnego, zawodowego, społecznego: „niema ani jednej czynności pojedynczego człowieka, która by w pewnej mierze nie wpłynęła na życie społeczeństwa; niema też ani jednej czynności zbiorowej, społecznej, która by się nie odbiła na jednostce, bo wszystko w społeczeństwie trzyma się razem i podtrzymuje wzajemnie, tak samo, jak w ciele ludzkim"60.

\section{Podsumowanie}

Niesprawiedliwość społeczna, jaka panowała na ziemiach polskich na początku XX wieku, zmuszała do podjęcia refleksji i nakreślenia planu naprawy ówczesnego porządku społecznego. Plan taki w swych pismach zawarł Aleksander Wóycicki można go nazwać wychowaniem do sprawiedliwości społecznej. Istotnym jego elementem jest rodzina.

W poglądach pedagogicznych oraz społecznych Wóycickiego rodzina warunkuje prawidłowe funkcjonowanie społeczeństwa, jest najlepszą szkołą społeczną i wychowawczą, czego autor dowodzi w swych pismach, podając szereg argumentów. Rodzina jest dla niego miniaturą społeczeństwa: wprowadza młodych ludzi, ucząc ich zasad w nim funkcjonujących. $\mathrm{W}$ istnieniu rodziny Wóycicki widzi korzyści nie tylko dla społeczeństwa, ale także dla wszystkich jej członków (zwalcza ona przykładowo egoizm i uczy poświęcenia). Stwierdza nawet, że ludzkość przetrwała dzięki dziedziczeniu poświęcenia obecnego w rodzinie. Wóycicki wyraża przekonanie o niemożności zastąpienia rodziny oraz jej ponadczasowości. Wszystko, co o pisze o rodzinie, doskonale zawiera się w stwierdzeniu, jakie o niej wypowiada: rodzina jest świątynią, a kobieta jej kapłanką.

Ważną kwestią była dla Wóycickiego, jako pedagoga rodziny, właśnie jej ochrona, zwłaszcza kobiety (matki) idzieci, co uznawał za niezbędne do prawidłowego funkcjonowania społeczeństwa. W swych pismach poruszał kwestię losu robotników (warunków mieszkaniowych, warunków pracy i skutkach jej braku, wyzysku robotnika ijego rodziny), ochrony prawnej kobiet (w tym matek i macierzyństwa), kwestię wychowania i kształcenia oraz opieki zdrowotnej i socjalnej.

\footnotetext{
${ }^{58}$ Aleksander Wóycicki, Podstawy moralne 8-godzinnego dnia pracy (Warszawa: Drukarnia Państwowa 1925), 8, $10-14$.

${ }^{59}$ Na mocy dekretu z 23 listopada 1918 r. wprowadzono 48 godzinny tydzień pracy. Ustawa zastępująca go 18 grudnia 1919 r. skracała ten czas do 46 godzin (6 godzin w sobotę). Źródło: Dz. U. 1920 nr 2 poz. 7.

${ }^{60}$ Wóycicki, Potęga, 7.
} 
Wyrażając pogląd, że wraz z upadkiem rodziny upada całe społeczeństwo, Wóycicki podkreślał istotę ochrony rodziny, co uznawał za główny obowiązek państwa i całego społeczeństwa. Ochrona ta miała się wyrażać w mądrym prawodawstwie, głównie w kwestii kobiet i dzieci, przy tworzeniu którego powinny współdziałać inicjatywa prywatna, państwowa i społeczna (przy czym Wóycicki podawał w swych pismach szereg propozycji poprawy położenia rodziny, zwłaszcza sytuacji kobiety i dzieci). Za niezbędne uznawał: poprawę warunków pracy oraz płacy, w tym zrównanie pensji kobiet i mężczyzn za taką samą pracę, ubezpieczenia rodzinne i zapomogi oraz płatne urlopy macierzyńskie. Wzorując się na tworzonych w krajach zachodnich przyfabrycznych żłobkach, chciał ich przeniesienia na grunt polski, widząc w nich, poza opieką dzienną dla dzieci matek pracujących, rozwiązanie kwestii karmienia piersią.

Pisma Wóycickiego zawierają też charakterystykę zagrożeń płynących wobec rodziny ze strony jej przeciwników. Do najważniejszych zaliczył socjalizm, neomaltuzjanizm, kapitalizm oraz emancypację kobiet rozumianą jako wyzwolenie ich z instytucji małżeństwa.

Plan naprawy, jaki nakreślił w swych pismach Aleksander Wóycicki jest bez wątpienia ponadczasowy i mógłby być z powodzeniem kontynuowany również współcześnie; przedstawione w niniejszym artykule jego szkicowe ujęcie wymagałoby jednak dalszych pogłębionych analiz.

Streszczenie: W pismach Aleksandra Wóycickiego zawarta jest promocja statusu rodziny i kobiety. Rodzinę uznaje za świątynię, a kobietę za jej kapłankę. Rodzina jako miniatura społeczeństwa stanowi fundament życia społecznego i narodu. Z upadkiem rodziny Wóycicki utożsamia upadek całego społeczeństwa. Jednak jego upadek wcześniej łączy z „upadkiem” kobiety - ma tu na myśli szeroką emancypację kobiet, która pozbawia ją ochrony ze strony mężczyzny. W swych tekstach Wóycicki kreśli również plany naprawy ówczesnej sytuacji rodziny, kobiety i jej dziecka. Plan ten zakłada prawo kobiety do jej ochrony oraz pracy, zwłaszcza w okresie ciąży i macierzyństwa, który może być wdrażany w obecnych czasach.

Słowa kluczowe: Aleksander Wóycicki, rodzina, ochrona rodziny, kobieta, sprawiedliwość społeczna

\section{Bibliografia}

Dekret z dnia 7 lutego 1919 r. o obowiązku szkolnym: Dz. Urz. Min. WRiOP, 1919, nr 2, poz. 2.

Kostkiewicz, Janina. Kierunki i koncepcje pedagogiki katolickiejw Polsce 1918-1939. Kraków: Wydawnictwo „Impuls”, 2013.

Kostkiewicz, Janina. „Krytyka warstwy wychowawczej totalitaryzmu komunistycznego lat dwudziestych i trzydziestych XX wieku w pismach Antoniego Szymańskiego”. W: W stużbie nauki, wychowania 
iwartości. Szkice biograficzne olubelskim środowisku naukowym, red. Ryszard Skrzyniarz, Małgorzata Łobacz, Barbara Borowska, 439-455. Lublin: Wydawnictwo EPISTEME, 2015.

Kostkiewicz, Janina. „Pedagogika rodziny w Polsce (1918-1939) - koncepcja i jej konteksty tworzone w kulturze katolickiej”. W: Janina Kostkiewicz, Milan Krankus, Ivan Podmanicki. Wychowanierodzina-społeczny rozwój osoby. Studia ze spotkań krakowsko-bratystawskich, 89-122. Kraków: Wyd. Uniwersytetu Jagiellońskiego, 2015.

Kostkiewicz, Janina. Wychowanie - rodzina - spoleczny rozwój osoby. Kraków: Wydawnictwo Uniwersytetu Jagiellońskiego, 2015.

Pius XI. „Divini Redemptoris - o bezbożnym komunizmie”. W: Socjalizm i komunizm potępiony przez papieży, red. Aneta Maniecka, 142-172. Sandomierz: Wydawnictwo Diecezjalne, 1937.

Podoleński, Stanisław. Rodzina w sowietach. Kraków: Wydawnictwo Księża Jezuici, 1938.

Podoleński, Stanisław. U progu. Książka dla młodych. Kraków: Wydawnictwo Apostolstwa Modlitwy, 1938.

Prokop, Krzysztof. „Prawo do ochrony zdrowia w świetle art. 68 Konstytucji RP”. W: Uwarunkowania systemu opieki zdrowotnej w Polsce: aspekty prawne i socjologiczne, red. Teresa Mróz, 34-51. Białystok: Wydawnictwo Temida 2, 2012.

Silska, Sylwia. Ewolucja poglądów na żywienie niemowląt w XIXi XX wieku. [praca doktorska]. Poznań 2013. Ustawa z dnia 18 grudnia 1919 r. o czasie pracy w przemyśle i handlu: Dz. U. $1920 \mathrm{nr} 2$ poz. 7.

Ustawa z dnia 2 lipca 1924 r. w przedmiocie pracy młodocianych i kobiet: Dz. U. 1924 nr 65 poz. 636.

Ustawa z dnia 11 marca 1932 r. o ustroju szkolnictwa: Dz. U. 1932 nr 38 poz. 389.

Wóycicki, Aleksander. Co tojest wspótczesny uniwersytet? Wyktad publiczny na rozpoczęcie roku akademickiego poprzedzony mową rektorska przy objęciu władzy w U.S.B. Wilno: Druk J. Zawadzki, 1938.

Wóycicki, Aleksander. Mowy rektorskie. Wilno: Druk J. Zawadzki, 1938.

Wóycicki, Aleksander. Podstawy moralne 8 godzinnego dnia pracy. Warszawa: Drukarnia Państwowa, 1925.

Wóycicki, Aleksander. Potęga przykładu. Warszawa: Księgarnia Polska Polskiej Macierzy Szkolnej, 1921.

Wóycicki, Aleksander. Religia i naród. Warszawa: Drukarnia K. Kopytowski i S-ka, 1918.

Wóycicki, Aleksander. Robotnik polski w życiu rodzinnym. Monografia społeczna, odbitka z Ekonomisty 1918-1922. Warszawa: Drukarnia I Litografia p. f. „Jan Cotty”, 1922.

Wóycicki, Aleksander. Rola wychowania w naprawie niesprawiedliwości społecznej. Poznań: Czcionkami Drukarni Wyd. Fr. Krajna, 1936.

Wóycicki, Aleksander. Wychowanie społeczeństwa. Lublin: Drukarnia „Narodowa”, 1938. www.kul.pl/ks-prof-aleksander-woycicki,art_26895.html [dostęp: 27.07.2016]. 